\title{
Assessment of Japanese iodine intake based on seaweed consumption in Japan: A literature- based analysis
}

\author{
Theodore T Zava and David T Zava*
}

\begin{abstract}
Japanese iodine intake from edible seaweeds is amongst the highest in the world. Predicting the type and amount of seaweed the Japanese consume is difficult due to day-to-day meal variation and dietary differences between generations and regions. In addition, iodine content varies considerably between seaweed species, with cooking and/or processing having an influence on iodine content. Due to all these factors, researchers frequently overestimate, or underestimate, Japanese iodine intake from seaweeds, which results in misleading and potentially dangerous diet and supplementation recommendations for people aiming to achieve the same health benefits seen by the Japanese. By combining information from dietary records, food surveys, urine iodine analysis (both spot and 24-hour samples) and seaweed iodine content, we estimate that the Japanese iodine intake-largely from seaweeds-averages 1,000-3,000 $\mu \mathrm{g} /$ day (1-3 mg/day).
\end{abstract}

Keywords: lodine, iodide, seaweed, algae, kelp, Japanese, thyroid, cancer, life expectancy

\section{Introduction}

Japanese iodine intake exceeds that of most other countries, primarily due to substantial seaweed consumption. Iodine is an essential element required for thyroid hormone synthesis, believed to impart some of its antioxidant and antiproliferative activity in the prevention of cardiovascular disease and cancer [1-8]. Seaweeds have the unique ability to concentrate iodine from the ocean, with certain types of brown seaweed accumulating over 30,000 times the iodine concentration of seawater [9]. The amount of iodine the Japanese consume daily from seaweeds has previously been estimated as high as 13.5 to $45 \mathrm{mg} /$ day by sources that use ambiguous data to approximate intake $[10,11]$, an amount 4.5 to 15 times greater than the safe upper limit of $3 \mathrm{mg} /$ day set by the Ministry of Health, Labor and Welfare in Japan [12]. While high iodine intake from seaweed consumption is believed to have numerous health benefits, it has been reported to negatively affect individuals with underlying thyroid disorders [13-16]. To prevent excessive consumption it is imperative for people seeking health benefits from a high iodine diet to be knowledgeable of the amount of iodine the Japanese consume daily. In this paper we use a combination of dietary records, food surveys, urine iodine analysis, and seaweed iodine content to provide a reliable estimate of Japanese iodine intake, primarily from seaweeds.

\section{Types of edible seaweeds and their iodine content}

In Japan, over 20 species of red, green, and brown algae (seaweed) are included in meals [17]. Iodine content varies depending on species, harvest location and preparation, and is typically highest in fresh cut blades and lowest in sun bleached blades [18]. The three most popular seaweed products in Japan are nori (Porphyra), wakame (Undaria) and kombu (Laminaria). Dried iodine contents range from $16 \mu \mathrm{g} / \mathrm{g}$ in nori to over $8,000 \mu \mathrm{g} / \mathrm{g}$ in kelp flakes; Japanese kombu and wakame contain an estimated $2353 \mu \mathrm{g} / \mathrm{g}$ and $42 \mu \mathrm{g} / \mathrm{g}$ respectively $[18,19]$. Ten different species of Laminaria, a type of kelp commonly labeled as kombu, from around the world were examined for their iodine content and were found to average $1,542 \mu \mathrm{g} / \mathrm{g}$ when dried [17].

\footnotetext{
* Correspondence: dzava@zrtlab.com

ZRT Laboratory, 8605 SW Creekside Place, Beaverton, 97008, USA
} 


\section{Japanese seaweed consumption statistics}

As the Japanese transitioned from a traditional to a Westernized diet, beginning around the 1950's [20], consumption of certain seaweed species declined while others increased. A decrease in kombu consumption (844 to $685 \mathrm{~g} /$ year per household) and an increase in wakame consumption (727 to $1234 \mathrm{~g} /$ year per household) can be seen between the years of 1963 and 1973 [21]. Consumption of kombu per Japanese household dropped further to $450 \mathrm{~g}$ in 2006 (elders ate up to four times more than those under the age of 29) [19]. Since daily seaweed consumption per person in Japan has remained relatively consistent over the last 40 years (4.3 $\mathrm{g} /$ day in 1955 and $5.3 \mathrm{~g} /$ day in 1995) [22], it is believed that consumption of wakame and nori have made up for the decline in kombu consumption [23,24]. Both nori and wakame have relatively low iodine contents compared to kombu.

Seaweed consumption frequency differs from person to person in Japan, resulting in a constantly fluctuating iodine intake. Seaweed is served in approximately $21 \%$ of Japanese meals [25] with $20-38 \%$ of the Japanese male and female population aged 40-79 years consuming seaweed more than five times per week, 29-35\% three to four times per week, $25-35 \%$ one to two times per week, $6-13 \%$ one to two times per month, and 1$2 \%$ rarely consuming seaweed [26]. A 2010 food frequency questionnaire on the Japanese Kombu Association website indicates that kelp (assuming kombu) is consumed at a rate of: $27.5 \%$ once per week, $25.5 \%$ once per month, $18 \%$ three or four times per week, and $15.9 \%$ once every few months, with only $6.1 \%$ of survey respondents stating they consume kelp nearly every day [27].

\section{Effect of cooking on seaweed iodine content}

Seaweed is often cooked to flavor dishes or soup stocks before consumption. When kombu is boiled in water for 15 minutes it can lose up to $99 \%$ of its iodine content, while iodine in sargassum, a similar brown seaweed, loses around 40\% [28,29]. Processed kelp is often boiled in dye for half an hour ("aokombu" or "kizami-kombu") before hanging to dry [21], a process which can reduce seaweed iodine content before it is consumed. When kelp is used to flavor soup stocks the seaweed is often removed after boiling, resulting in soup stock high in iodine. Twenty samples of supermarket soups with kelp or kelp broth were analyzed by Nishiyama et al. to determine iodine content, revealing a minimum concentration of $660 \mu \mathrm{g} / \mathrm{L}$ $(0.66 \mathrm{mg} / \mathrm{L})$ and a maximum concentration of 31,000 $\mu \mathrm{g} / \mathrm{L}(31 \mathrm{mg} / \mathrm{L})$ [16]. Serving size for soup is typically around $0.25 \mathrm{~L}$, resulting in 165 to $7,750 \mu \mathrm{g}(0.165$ to $7.75 \mathrm{mg}$ ) of iodine per serving.

\section{Estimating Japanese iodine intake from seaweed consumption}

Due to variation of iodine content from one seaweed species to the next, along with confusion stemming from wet and dry weight terminology, many inaccurate assumptions have been made regarding the amount of iodine the Japanese actually consume from seaweed. Not all studies, dietary records or surveys specify whether daily or yearly consumption of seaweeds is recorded using wet weight, dry weight or a combination of the two. In some reports seaweed consumption has been estimated at 4-7 g/day dried weight $[17,22,30,31]$, while other reports claim consumption of $12 \mathrm{~g} /$ day using both wet and dry weight [32]. Certain seaweeds have a swelling capacity of nearly ten times their dry volume with moisture content typically over $70 \%$ when wet and around $7-20 \%$ when dried $[33,34]$. The difference between wet and dry weight, along with the type of seaweeds being consumed, can result in extreme overestimation (more likely) or underestimation (less likely) of Japanese iodine intake.

Interpreting information to determine Japanese seaweed consumption and resulting iodine intake is a difficult task, and with ever changing diets, a close estimate is all that can be made. Nori and wakame are the most commonly consumed seaweeds in Japan, with nori accounting for $45 \%$ and wakame accounting for $30 \%$ (75\% together) of total seaweed consumption, as stated by the Food and Agriculture Organization of the United Nations [35]. Based on previous estimates and records, dried seaweed consumption of 4-7 g/day [17,22,30,31] results in iodine intakes between 79 and $139 \mu \mathrm{g} /$ day from nori and wakame when calculated using dried iodine contents of 16 and $42 \mu \mathrm{g} / \mathrm{g}$ respectively [18]. The remainder of iodine intake is derived mainly from kombu consumption, with smaller amounts coming from other seaweeds that have nominal iodine content.

Kombu has the highest iodine content of all seaweeds in the Japanese diet. In 2006 consumption of kombu/ household/year was $450 \mathrm{~g}$ [19], and with an average of 2.55 members per household in Japan in 2005 [36], 0.48 $\mathrm{g} \mathrm{kombu} /$ person/day was consumed. When calculated, $0.48 \mathrm{~g}$ of kombu with an iodine content of $2,353 \mu \mathrm{g} / \mathrm{g}$ [18] equates to $1,129 \mu \mathrm{g} /$ day of iodine. Assuming negligible iodine intake from the other seaweeds consumed, daily iodine intake from nori, wakame, and kelp can be estimated at 1,208 to $1,268 \mu \mathrm{g} /$ day ( 1.2 to $1.3 \mathrm{mg} /$ day). It is reasonable to assume that iodine intake per day based on seaweed consumption frequency and iodine content averages around 1,000-2,000 $\mu \mathrm{g} /$ day (1-2 mg/day).

\section{Estimating Japanese iodine intake from diet studies and urine iodine analysis}

Seaweed consumption statistics only provide only an estimate of Japanese iodine intake and should be 
combined with other predictive factors. Fortunately, studies that measure iodine content of single or entire meals are available and are, arguably, the most accurate estimate of Japanese iodine intake from seaweeds. A collection of Japanese diet studies that measure the amount of iodine in 24-hour diet samples or single meals can be seen in Table 1. Daily iodine intake of the Japanese based on 24-hour diet samples generally does not exceed 3,000 $\mu \mathrm{g}(3 \mathrm{mg})$.

Because approximately $97 \%$ of dietary iodine is excreted in the urine, urine iodine levels taken from individuals or populations can provide a secondary estimate of Japanese iodine intake from seaweed consumption, when paired with diet studies $[37,38]$. Urine iodine levels can increase from $100 \mu \mathrm{g} / \mathrm{L}$ to $30,000 \mu \mathrm{g} / \mathrm{L}$ in a single day and return to $100 \mu \mathrm{g} / \mathrm{L}$ within a couple of days, depending on seaweed intake [39]. This is somewhat expected when varying amounts and types of seaweeds are consumed on a day-to-day basis. Urine creatinine levels seen as $\mu$ g iodine/g creatinine ( $\mu \mathrm{g} / \mathrm{g} \mathrm{Cr})$ can be used to adjust for an individual's hydration status, correlating well with $\mu \mathrm{g} / \mathrm{L}$ in areas of adequate nutrition [40]. Urine iodine levels of the Japanese found in a number of studies are shown in Table 2. Mean and median iodine levels in the Japanese urine collections typically do not exceed 3,000 $\mu \mathrm{g} / \mathrm{L}(3 \mathrm{mg} / \mathrm{L})$.

Table 1 Compilation of Japanese diet studies measuring iodine in 24-hour diet samples and single meals

\begin{tabular}{|c|c|c|c|c|c|c|}
\hline $\begin{array}{l}\text { Author(s) } \\
\text { [source] }\end{array}$ & Year & $\begin{array}{l}\text { Number of } \\
\text { Participants }\end{array}$ & $\begin{array}{l}\text { Mean lodine in } 24-\text { Hour } \\
\text { Diet Sample }(\mu \mathrm{g})\end{array}$ & $\begin{array}{l}\text { Lowest lodine in } 24-\text { Hour } \\
\text { Diet Sample }(\mu \mathrm{g})\end{array}$ & $\begin{array}{c}\text { Highest lodine in } 24 \text {-Hour } \\
\text { Diet Sample }(\mu \mathrm{g})\end{array}$ & $\begin{array}{l}\text { City/ } \\
\text { Region }\end{array}$ \\
\hline $\begin{array}{l}\text { Katamine et al. } \\
\text { [23] }\end{array}$ & 1986 & 1 & $1023 \mu \mathrm{g}$ & $45 \mu \mathrm{g}$ & $1921 \mu \mathrm{g}$ & Tokyo \\
\hline $\begin{array}{c}\text { Katamine et al. } \\
{[23]}\end{array}$ & 1986 & 1 & $362 \mu \mathrm{g}$ & $57 \mu \mathrm{g}$ & $1244 \mu \mathrm{g}$ & Tokyo \\
\hline $\begin{array}{c}\text { Katamine et al. } \\
{[23]}\end{array}$ & 1986 & 1 & $361 \mu \mathrm{g}$ & $62 \mu \mathrm{g}$ & $1098 \mu \mathrm{g}$ & Tokyo \\
\hline $\begin{array}{l}\text { Katamine et al. } \\
{[23]}\end{array}$ & 1986 & 1 & $429 \mu \mathrm{g}$ & $52 \mu \mathrm{g}$ & $1561 \mu \mathrm{g}$ & Tokyo \\
\hline $\begin{array}{c}\text { Katamine et al. } \\
\text { [23] }\end{array}$ & 1986 & 10 (hospital) & $1290 \mu \mathrm{g}$ & $89 \mu \mathrm{g}$ & $4746 \mu \mathrm{g}$ & \\
\hline $\begin{array}{l}\text { Katamine et al. } \\
\text { [23] }\end{array}$ & 1986 & 5 (hospital) & $195 \mu \mathrm{g}$ & $95 \mu \mathrm{g}$ & $287 \mu \mathrm{g}$ & \\
\hline $\begin{array}{c}\text { Katamine et al. } \\
{[23]}\end{array}$ & 1986 & 13 (school) & $113 \mu \mathrm{g} / \mathrm{meal}$ & $47 \mu \mathrm{g} / \mathrm{meal}$ & $203 \mu \mathrm{g} / \mathrm{meal}$ & Ibaraki \\
\hline $\begin{array}{l}\text { Katamine et al. } \\
{[23]}\end{array}$ & 1986 & 5 (school) & $27 \mu \mathrm{g} /$ meal & $25 \mu \mathrm{g} / \mathrm{meal}$ & $31 \mu \mathrm{g} / \mathrm{meal}$ & Kanagawa \\
\hline $\begin{array}{l}\text { Katamine et al. } \\
\text { [23] }\end{array}$ & 1986 & 5 (school) & $36 \mu \mathrm{g} /$ meal & $18 \mu \mathrm{g} / \mathrm{meal}$ & $43 \mu \mathrm{g} / \mathrm{meal}$ & Kanagawa \\
\hline Tajiri et al. [48] & 1986 & 1 & $25400 \mu \mathrm{g}$ est. & & & Kumamoto \\
\hline Tajiri et al. [48] & 1986 & 1 & $43000 \mu \mathrm{g}$ est. & & & Kumamoto \\
\hline Tajiri et al. [48] & 1986 & 1 & $15000 \mu \mathrm{g}$ est. & & & Kumamoto \\
\hline Tajiri et al. [48] & 1986 & 1 & $20000 \mu \mathrm{g}$ est. & & & Kumamoto \\
\hline Tajiri et al. [48] & 1986 & 10 & $2800 \mu \mathrm{g}$ est. & & & Kumamoto \\
\hline Tajiri et al. [48] & 1986 & 8 & $2300 \mu \mathrm{g}$ est. & & & Kumamoto \\
\hline $\begin{array}{c}\text { Shiraishi et al. } \\
\text { [61] }\end{array}$ & 1999 & 6 & $1770 \mu \mathrm{g}$ & $545 \mu \mathrm{g}$ & $4490 \mu \mathrm{g}$ & Mito \\
\hline $\begin{array}{l}\text { Kunachowicz } \\
\text { et al. [62] }\end{array}$ & 2000 & 5 & $\begin{array}{l}1970 \mu \mathrm{g} / \mathrm{kg} \text { mean, } 550 \mu \mathrm{g} / \mathrm{kg} \\
\text { median }\end{array}$ & $88 \mu \mathrm{g} / \mathrm{kg}$ & $7650 \mu \mathrm{g} / \mathrm{kg}$ & \\
\hline $\begin{array}{l}\text { Yoshinaga et } \\
\text { al. [25] }\end{array}$ & 2001 & 29 (476 meals) & $1900 \mu \mathrm{g} / \mathrm{kg}$ & & & All Japan \\
\hline $\begin{array}{c}\text { Kucera et al. } \\
\text { [63] }\end{array}$ & 2003 & & 756 g/kg median & $124 \mu \mathrm{g} / \mathrm{kg}$ & $21660 \mu \mathrm{g} / \mathrm{kg}$ & \\
\hline $\begin{array}{l}\text { Nishiyama et } \\
\text { al. [16] }\end{array}$ & 2004 & 5 (pregnant) & & $2280 \mu \mathrm{g}$ & $3180 \mu \mathrm{g}$ & Kumamoto \\
\hline $\begin{array}{l}\text { Nishiyama et } \\
\text { al. [16] }\end{array}$ & 2004 & 10 (pregnant) & & $820 \mu \mathrm{g}$ & $1400 \mu \mathrm{g}$ & Kumamoto \\
\hline $\begin{array}{l}\text { Nishiyama et } \\
\text { al. [16] }\end{array}$ & 2004 & $\begin{array}{l}22 \text { (pregnant w/ } \\
\text { no kelp) }\end{array}$ & & $250 \mu \mathrm{g}$ & $480 \mu \mathrm{g}$ & Kumamoto \\
\hline
\end{tabular}


Table 2 Compilation of Japanese urine iodine studies

\begin{tabular}{|c|c|c|c|c|c|c|c|}
\hline $\begin{array}{c}\text { Author(s) } \\
\text { [source] }\end{array}$ & Year & $\begin{array}{c}\text { Number of } \\
\text { participants }\end{array}$ & Age & Sex & $\begin{array}{l}\text { Mean Urine lodine ( } \mu \mathrm{g} / \mathrm{L}, \mu \mathrm{g} / \mathrm{g} \mathrm{Cr} \text {, } \\
\text { or } \mu \mathrm{g} / 24 \text {-hour) }\end{array}$ & $\begin{array}{l}\text { Median Urine } \\
\text { lodine ( } \mu \mathrm{g} / \mathrm{L})\end{array}$ & City/Region \\
\hline Suzuki et al. [50] & 1965 & 2 & & & $1565 \mu \mathrm{g} / 24$-hour (hospital diet) & & Hokkaido \\
\hline Suzuki et al. [50] & 1965 & 5 & & & $23300 \mu \mathrm{g} / 24$-hour (seaweed diet) & & Hokkaido \\
\hline Suzuki et al. [50] & 1965 & 7 & & & 175 mg/24-hour (iodine restricted) & & Hokkaido \\
\hline $\begin{array}{c}\text { Nagataki et al. } \\
\text { [39] }\end{array}$ & 1967 & 9 & & Both & $3286 \mu \mathrm{g} / 24$-hour & & Tokyo \\
\hline Suzuki et al. [64] & 1985 & 5 & $19-26$ & Male & $357 \mu \mathrm{g} / 24$-hour & & \\
\hline Suzuki et al. [64] & 1985 & 10 & $19-21$ & Male & $149 \mu \mathrm{g} / 24$-hour & & \\
\hline Yabu et al. [65] & 1986 & 127 & 18-57 & Both & $3238 \mu \mathrm{g} / \mathrm{L}$ & & \\
\hline Yabu et al. [66] & 1988 & 127 & $18-57$ & Both & $3022 \mu \mathrm{g} / \mathrm{g} \mathrm{Cr}$ & & \\
\hline Yabu et al. [66] & 1988 & 43 & $4-10$ & Both & $2756 \mu \mathrm{g} / \mathrm{g} \mathrm{Cr}$ & & \\
\hline Yabu et al. [66] & 1988 & 30 & Infant & Both & $1854 \mu \mathrm{g} / \mathrm{g} \mathrm{Cr}$ & & \\
\hline Yabu et al. [66] & 1988 & 24 & $11-32$ & Female & $1701 \mu \mathrm{g} / \mathrm{g} \mathrm{Cr}$ & & \\
\hline Yabu et al. [66] & 1988 & 73 & $18-27$ & Female & $2845 \mu \mathrm{g} / \mathrm{g} \mathrm{Cr}$ & & \\
\hline Nagataki [67] & 1993 & 14 & & & $660 \mu \mathrm{g} / \mathrm{g} \mathrm{Cr}$ & & Tohoku \\
\hline Nagataki [67] & 1993 & 13 & & & 1090 mg/g Cr (hospital diet) & & Tohoku \\
\hline Nagataki [67] & 1993 & 13 & & & $1760 \mu \mathrm{g} / \mathrm{g} \mathrm{Cr}$ (hospital diet) & & Tokyo \\
\hline Nagataki [67] & 1993 & 22 & & & $1460 \mu \mathrm{g} / \mathrm{g} \mathrm{Cr}$ (hospital diet) & & Shinsyu \\
\hline Nagataki [67] & 1993 & 8 & & & $1370 \mu \mathrm{g} / \mathrm{g} \mathrm{Cr}$ (hospital diet) & & Kyoto \\
\hline Nagataki [67] & 1993 & 19 & & & $910 \mu \mathrm{g} / \mathrm{g} \mathrm{Cr}$ (hospital diet) & & Nagasaki \\
\hline Konno et al. [49] & 1994 & 4138 & $\begin{array}{c}\text { Mean } \\
\sim 45 \\
\end{array}$ & Both & $3300 \mu \mathrm{g} / \mathrm{L}$ & & Sapporo \\
\hline Tsuda et al. [68] & 1995 & 84 & & & & $596 \mu \mathrm{g} / \mathrm{L}$ & Nagasaki \\
\hline Nagata et al. [47] & 1998 & 150 & $\begin{array}{c}\text { Mean } \\
\sim 52\end{array}$ & Both & $1480 \mu \mathrm{g} / \mathrm{L}$ & & Nishihara \\
\hline Nagata et al. [47] & 1998 & 37 & & & $1470 \mu \mathrm{g} / 24$-hour & & Nishihara \\
\hline Nagata et al. [47] & 1998 & 20 & $\begin{array}{c}\text { Mean } \\
\sim 51\end{array}$ & Both & $1620 \mu \mathrm{g} / \mathrm{L}$ & & Yamagata \\
\hline Nagata et al. [47] & 1998 & 54 & $\begin{array}{c}\text { Mean } \\
\sim 49 \\
\end{array}$ & Both & $1200 \mu \mathrm{g} / \mathrm{L}$ & & Kobe \\
\hline Nagata et al. [47] & 1998 & 80 & $\begin{array}{l}\text { Mean } \\
\sim 50\end{array}$ & Both & $810 \mu \mathrm{g} / \mathrm{L}$ & & Hotaka \\
\hline Ishigaki et al. [69] & 2001 & 250 & $7-14$ & Both & & $362 \mu \mathrm{g} / \mathrm{L}$ & Nagasaki \\
\hline Ishigaki et al. [69] & 2001 & 50 & Adult & Both & & $208 \mu \mathrm{g} / \mathrm{L}$ & Hamamatsu \\
\hline Ishigaki et al. [69] & 2001 & 50 & Adult & Both & & $1015 \mu \mathrm{g} / \mathrm{L}$ & $\begin{array}{l}\text { South } \\
\text { Kayabe }\end{array}$ \\
\hline $\begin{array}{c}\text { Takamura et al. } \\
{[70]} \\
\end{array}$ & 2003 & 4 & $18-24$ & Male & $406 \mu \mathrm{g} / \mathrm{L}$ & & Nagasaki \\
\hline $\begin{array}{l}\text { Zimmermann et } \\
\text { al. [71] }\end{array}$ & 2005 & 302 & $6-12$ & Both & $296 \mu \mathrm{g} / \mathrm{L}$ & $292 \mu \mathrm{g} / \mathrm{L}$ & $\begin{array}{l}\text { Central } \\
\text { Hokkaido }\end{array}$ \\
\hline $\begin{array}{l}\text { Zimmermann et } \\
\text { al. [71] }\end{array}$ & 2005 & 280 & $6-12$ & Both & $728 \mu \mathrm{g} / \mathrm{L}$ & $741 \mu \mathrm{g} / \mathrm{L}$ & $\begin{array}{l}\text { Costal } \\
\text { Hokkaido }\end{array}$ \\
\hline $\begin{array}{c}\text { Tomoda et al. } \\
{[72]}\end{array}$ & 2005 & 47 & $\begin{array}{l}\text { Mean } \\
\sim 53\end{array}$ & Both & $428 \mu \mathrm{g} / \mathrm{g} \mathrm{Cr}$ & & \\
\hline $\begin{array}{c}\text { Tomoda et al. } \\
\text { [72] }\end{array}$ & 2005 & 21 & $\begin{array}{c}\text { Mean } \\
\sim 56\end{array}$ & Both & $587 \mu \mathrm{g} / \mathrm{g} \mathrm{Cr}$ & & \\
\hline Fuse et al. [73] & 2007 & 654 & $6-12$ & Both & & $281 \mu \mathrm{g} / \mathrm{L}$ & Tokyo \\
\hline Miyai et al. [74] & 2008 & 6 & $\begin{array}{l}\text { Mean } \\
\sim 27\end{array}$ & Both & $560 \mu \mathrm{g} / 24$-hour & & \\
\hline Miyai et al. [74] & 2008 & 14 & $\begin{array}{l}\text { Mean } \\
\sim 27\end{array}$ & Both & $1110 \mu \mathrm{g} / 24$-hour & & \\
\hline Orito et al. [75] & 2009 & 514 & Adult & $\begin{array}{l}\text { Female } \\
\text { (pregnant) }\end{array}$ & & $328 \mu \mathrm{g} / \mathrm{L}$ & Kobe \\
\hline
\end{tabular}


When using 1.5 $\mathrm{L}$ as an expected 24-hour urine output, urine iodine excretion should rarely exceed an estimated $4,500 \mu \mathrm{g} / 24 \mathrm{hr}(4.5 \mathrm{mg} / 24 \mathrm{hr})$.

\section{Japanese health statistics linked to high seaweed intake}

The Japanese are considered one of the world's longest living people, with an extraordinarily low rate of certain types of cancer. A major dietary difference that sets Japan apart from other countries is high iodine intake, with seaweeds the most common source. Here are some astonishing Japanese health statistics, which are possibly related to their high seaweed consumption and iodine intake:

-Japanese average life expectancy ( 83 years) is five years longer than US average life expectancy ( 78 years) [41].

-In 1999 the age-adjusted breast cancer mortality rate was three times higher in the US than in Japan [42].

-Ten years after arriving in the US (in 1991), the breast cancer incidence rate of immigrants from Japan increased from 20 per 100,000 to 30 per 100,000 [43].

-In 2002 the age-adjusted rate of prostate cancer in Japan was 12.6 per 100,000 , while the US rate was almost ten times as high [44].

-Heart related deaths in men and women aged 35-74 years are much higher in the US $(1,415$ per 100,000$)$ as they are in Japan (897 per 100,000) [45].

-In 2004, infant deaths were over twice as high in the US $(6.8$ per 1,000$)$ as they were in Japan $(2.8$ per 1,000$)$ [46].

\section{Negative effects of iodine from seaweed}

High iodine intake from seaweed consumption can cause unexpected health problems in a subset of individuals with pre-existing thyroid disorders. Although it is reported that excessive iodine does not cause thyroid antibody positivity, high intake can cause or worsen symptoms for people with previous thyroid autoimmunity or other underlying thyroid issues [47]. Transient hypothyroidism and iodine-induced goiter is common in Japan and can be reversed in most cases by restricting seaweed intake [16,29,48-52]. In Asian cultures, seaweed is commonly cooked with foods containing goitrogens such as broccoli, cabbage, bok choi and soy [18]. The phytochemicals in these foods can competitively inhibit iodine uptake by the thyroid gland (i.e., isothiocyanates from cruciferous vegetables) [53-55], or inhibit incorporation of iodine into thyroid hormone (i.e., soy isoflavones) [56,57].

Certain species of seaweed can concentrate bromine, a halide similar to iodine with no known physiological function, at very high levels $[58,59]$. If seaweeds with elevated levels of bromine and low levels of iodine are consumed when the body is in an iodine deficient state, inhibition of thyroid hormone synthesis-due to bromine's attachment to tyrosine residues on thyroglobulin in place of iodine-is plausible [60].

\section{Estimate of daily iodine intake in Japan}

We estimate that the average Japanese iodine intake, largely from seaweed consumption-based on dietary records, food surveys, urine iodine analysis and seaweed iodine content-is 1,000-3,000 $\mu \mathrm{g} /$ day (1-3 $\mathrm{mg} /$ day). This estimate compares to a recent report claiming that the average iodine intake of the Japanese from kelp is around $1,200 \mu \mathrm{g} /$ day $(1.2 \mathrm{mg} /$ day $)$ [19]. Iodine intake can vary from day-to-day depending on diet, and it is unlikely for a single persons iodine intake to remain constant for an extended period of time. With the multitude of edible seaweeds (each with different iodine content) consumed in the Japanese diet, it is not appropriate to use a single type of seaweed to determine iodine intake, though many estimates do. Although seaweed provides a majority of the Japanese iodine intake, other food sources (containing far less iodine)-such as fish and shellfish-can increase the total amount of iodine consumed daily.

\section{Conclusions}

Japanese iodine intake from seaweed is linked to health benefits not seen in cultures with dissimilar diets. Knowing how much iodine the Japanese consume daily is beneficial for people who wish to consume equivalent amounts of iodine or seaweed supplements while avoiding excessive amounts that may adversely affect health.

\section{Abbreviations \\ Cr: Creatinine.}

\section{Authors' contributions}

TZ acquired and compiled data shown in this study, interpreted data, and provided intellectual content. DZ provided interpretation of data and intellectual content. All authors read and approved the final manuscript.

\section{Authors' information}

TZ received his Bachelor's degree in Biology from Oregon State University in 2009. He is a Research Associate at ZRT Laboratory in Beaverton, Oregon, where he recently developed a test to measure iodine and creatinine levels in dried urine. His current research focuses on iodine deficiency, Japanese iodine intake, halide competition, thyroid disorders and iodine kinetics in the human body.

DZ received his doctorate in Biochemistry from the University of Tennessee in 1974. He is Laboratory Director and President of ZRT Laboratory, which he founded in 1998. Dr. Zava has developed innovative, simple and costeffective methods to monitor hormone and other analytes associated with health and disease. His current research focus includes endocrinology, breast cancer, and-most recently-the importance of iodine to optimum health. He is co-author of a landmark book, What Your Doctor May Not Tell You About Breast Cancer: How Hormone Balance Can Help Save Your Life.

\section{Competing interests}

The author declares that they have no competing interests. 
Received: 26 August 2011 Accepted: 5 October 2011

Published: 5 October 2011

\section{References}

1. Cann SA: Hypothesis: dietary iodine intake in the etiology of cardiovascular disease. J Am Coll Nutr 2006, 25:1-11.

2. Miller DW: Extrathyroidal Benefits of lodine. J Am Phys and Surg 2006, 11:106-110.

3. Cann SA, van Netten JP, Glover DW, van Netten C: lodide accumulation in extrathyroidal tissues. J Clin Endocrinol Metab 1999, 84:821-822.

4. Yuan $\mathrm{YV}$, Walsh NA: Antioxidant and antiproliferative activities of extracts from a variety of edible seeweeds. Food Chem Toxicol 2006, 44:1144-1150.

5. Venturi S: Is there a role for iodine in breast diseases? Breast 2001, 10:379-382.

6. Winkler R, Griebenow S, Wonisch W: Effect of iodide on total antioxidant status of human serum. Cell Biochem Funct 2000, 18:143-146.

7. Moser $\mathrm{M}$, Buchberger $\mathrm{W}$, Mayer $\mathrm{H}$ : Influence of an iodine-drinking cure on the antioxidative status of diabetes patients. Wien Klin Wochenschr 1991, 103:183-186.

8. Venturi S, Donati FM, Venturi A, Venturi M, Grossi L, Guidi A: Role of iodine in evolution and carcinogenesis of thyroid, breast and stomach. Adv Clin Path 2000, 4:11-17.

9. Küpper FC, Schweigert N, Ar Gall E, Legendre J-M, Vilter H, Kloareg B: lodine uptake in Laminariales involves extracellular, haloperoxidasemediated oxidation of iodide. Planta 1998, 207:163-671.

10. Abraham GE, Brownstein D: Validation of the orthoiodosupplementation program: a rebuttal of Dr. Gaby's editorial on iodine. The Original Internist 2005, 12:184-194.

11. Miller D: lodine for health. 2006 [http://www.lewrockwell.com/miller/ miller20.html].

12. The Ministry of Health, Labour, and Welfare, Japan: Dietary reference intakes for Japanese. In the Ministry of Health, Labour, and Welfare Daiichi Shuppan Publishing. Tokyo; 2005, 189-193.

13. Mussig K, Thamer C, Bares R, Lipp HP, Haring HU, Gallwitz B: lodineinduced thyrotoxicosis after ingestion of kelp-containing tea. J Gen Intern Med 2006, 21:C11-C14.

14. Laurberg P, Pedersen IB, Knudsen N, Ovesen L, Andersen S: Environmental iodine intake affects the type of non-malignant thyroid disease. Thyroid 2001, 11:457-469.

15. Markou K, Georgopoulos N, Kyriazopoulou V, Vagenakis AG: lodine-induced hypothyroidism. Thyroid 2001, 11:501-510.

16. Nishiyama S, Mikeda T, Okada T, Nakamura K, Kotani T, Hishinuma: Transient hypothyroidism or persistent hyperthyrotropinemia in neonates born to mothers with excessive iodine intake. Thyroid 2004, 14:1077-1083.

17. Arasaki S, Arasaki T: Vegetables from the sea Tokyo: Japan Publications Inc; 1983.

18. Teas J, Pino S, Critchley AT, Braverman LE: Variability of iodine content in common commercially available edible seaweeds. Thyroid 2004, 14:836-841.

19. Nagataki $\mathrm{S}$ : The average of dietary iodine intake due to the ingestion of seaweeds is $1.2 \mathrm{mg} /$ day in Japan. Thyroid 2008, 18:667-668.

20. Drewnowski A, Popkin BM: The nutrition transition: new trends in the global diet. Nutr Rev 1997, 55:31-43.

21. Naylor J: Production, trade and utilization of seaweeds and seaweed products. FAO Fish Tech Pap 159, FAO, Rome 1976.

22. Matsumura Y: Nutrition trends in Japan. Asia Pac J Clin Nutr 2001, 10 S40-S47.

23. Katamine S, Mamiya Y, Sekimoto K, Hoshino N, Totsuka K, Naruse U, Watabe A, Sugiyama R, Suzuki M: lodine content of various meals currently consumed by urban Japanese. J Nutr Sci Vitaminol 1986, 32:487-495.

24. Research Division, Minister's Secretariat, Ministry of Agriculture, Forestry and Fisheries of Japan: Food balance sheet in 1979 Tokyo; 1981, 107-108.

25. Yoshinaga J, Morita M, Yukawa M, Shiraishi K, Kawamura H: Certified reference material for analytical quality assurance of minor and trace elements in food and related matrixes based on a typical Japanese diet: interlaboratory study. J AOAC Int 2001, 84:1202-1208.

26. Iso H, Date C, Noda H, Yoshimura T, Tamakoshi A, JACC Study Group: Frequency of food intake and estimated nutrient intake among men and women: the JACC Study. J Epidemiol 2005, 15:S24-S42.
27. Nihon Konbu Kyoukai (Japan Konbu Association) in Konbu-Net: 2nd Kelp Report. [http://www.kombu.or.jp/btob/data2010-2.pdf].

28. Hou X, Chai C, Qian Q, Yan X, Fan X: Determination of chemical species of iodine in some seaweeds. Sci Total Environ 1997, 204:215-221.

29. Ishizuki Y, Yamauchi K, Miura Y: Transient thyrotoxicosis induced by Japanese kombu. Nippon Naibunpi Gakkai Zasshi 1989, 65:91-98.

30. Toyokawa H: Nutritional status in Japan from the view-point of numerical ecology. Soc Sci Med 1978, 12:517-524.

31. Matsuzaki S, Iwamura K: Application of seaweeds to human nutrition and medicine. In Nahrung aus dem Meer; Food from the sea New York: Springer; 2001, 162-184.

32. Teas J, Baldeon ME, Chiriboga DE, Davis JR, Sarries AJ, Braverman LE: Could dietary seaweed reverse the metabolic syndrome? Asia Pac J Clin Nutr 2009, 18:145-154.

33. Teas J, Hurley TG, Hebert JR, Franke AA, Sepkovic DW, Kurzer MS: Dietary seaweed modifies estrogen and phytoestrogen metabolism in healthy postmenopausal women. J Nutr 2009, 139:939-944.

34. Murata M, Nakazoe J: Production and use of marine algae in Japan. Jpn Agr Res Q 2001, 35:281-290.

35. Rajadurai MR: Production, marketing and trade of seaweeds.Philippines2731 Aug 1990.

36. Statistics Bureau, Ministry of Internal Affairs and Communications, Government of Japan: Chapter IX: Household and household status [http:// www.stat.go.jp/english/data/kokusei/2005/poj/pdf/2005ch09.pdf].

37. Hays MT: Estimation of total body iodine content in normal young men. Thyroid 2001, 11:671-675.

38. Larsen PR, Davies TF, Hay ID: The thyroid gland. In In Williams textbook of endocrinology. Edited by: Wilson JD, Foster DW, Kronenberg HM, Larson P. Philadelphia: W.B. Saunders Company; 1998:390-151.

39. Nagataki S, Shizume K, Nakao K: Thyroid function in chronic excess iodide ingestion: comparison of thyroidal absolute iodine uptake and degradation of thyroxine in euthyroid Japanese subjects. J Clin Endocrinol Metab 1967, 27:638-647.

40. Caldwell KL, Makhmudov A, Ely E, Jones RL, Wang RY: lodine status of the U.S. population, National Health and Nutrition Examination Survey, 2005-2006 and 2007-2008. Thyroid 2011, 21:419-27.

41. World Health Organization: World health statistics 2010: Geneva, Switzerland [http://www.who.int/gho/database/WHS2010_Part2.xls].

42. Mettlin C: Global breast cancer mortality statistics. CA Cancer J Clin 1999, 49:138-144.

43. Shimizu H, Ross RK, Bernstein L, Yatani R, Henderson BE, Mack TM: Cancers of the prostate and breast among Japanese and white immigrants in Los Angeles County. Br J Cancer 1991, 63:963-966.

44. International Agency for Research on Cancer: Globocan 2002 Database [http://www-dep.iarc.fr/].

45. Roger VL, Go AS, Lloyd-Jones DM, Adams RJ, Berry JD, Brown TM, Carnethon MR, Dai S, de Simone G, Ford ES, Fox CS, Fullerton HJ, Gillespie C, Greenlund KJ, Hailpern SM, Heit JA, Ho PM, Howard VJ, Kissela BM, Kittner SJ, Lackland DT, Lichtman JH, Lisabeth LD, Makuc DM, Marcus GM, Marelli A, Matchar DB, McDermott MM, Meigs JB, Moy CS, et al: Heart Disease and Stroke Statistics-2011 Update: A Report From the American Heart Association. Circulation 2011, 123:e18-e209.

46. National Center for Health Statistics: Health, United States, 2007. With chartbook on trends in the health of Americans. Hyattsville, MD; 2007 [http://www.cdc.gov/nchs/data/hus/hus07.pdf\#listtables].

47. Nagata K, Takasu N, Akamine H, Ohshiro C, Komiya I, Murakami K, Suzawa A, Nomura T: Urinary iodine and thyroid antibodies in Okinawa, Yamagata, Hyogo, and Nagano, Japan: the differences in iodine intake do not affect thyroid antibody positivity. Endocr J 1998, 45:797-803.

48. Tajiri J, Higashi K, Morita M, Umeda T, Sato T: Studies of hypothyroidism in patients with high iodine intake. J Clin Endocrinol Metab 1986, 63:412-417.

49. Konno N, Makita H, Yuri K, lizuka N, Kawasaki K: Association between dietary iodine intake and prevalence of subclinical hypothyroidism in the central regions of Japan. J Clin Endocrinol Metab 1994, 78:393-397.

50. Suzuki H, Hiquchi T, Sawa K, Ohtaki S, Horiuchi Y: "Endemic coast goiter" in Hokkaido, Japan. Acta Endocrinol (Copenh) 1965, 50:161-176.

51. Konno N, Yuri K, Taguchi H, Miura K, Taguchi S, Hagiwara K, Murakami S: Screening for thyroid diseases in an iodine sufficient area with sensitive thyrotrophin assays, and serum thyroid autoantibody and urinary iodide determinations. Clin Endocrinol (Oxf) 1993, 38:273-281. 
52. Kasagi K, Iwata M, Misaki T, Konishi J: Effect of iodine restriction on thyroid function in patients with primary hypothyroidism. Thyroid 2003, 13:561-567.

53. Greer MA, Astwood EB: The antithyroid effect of certain foods in man as determined with radioactive iodine. Endocrinology 1948, 43:105-119.

54. Renner R: More lodine or Less Perchlorate? Environ Health Perspect 2010, 118:a289-a289.

55. Zimmermann MB: lodine deficiency. Endocr Rev 2009, 30:376-408

56. Doerge DR, Sheehan DM: Goitrogenic and estrogenic activity of soy isoflavones. Environ Health Perspect 2002, 110(suppl 3):349-353.

57. Doerge DR, Chang HC: Inactivation of thyroid peroxidase by soy isoflavones, in vitro and in vivo. J Chromatogr B Anal Technol Biomed Life Sci 2002, 777:269-279.

58. Saenko GN, Kravtsova YY, Ivanenko W, Sheludko SI: Concentration of iodine and bromine by plants in the Seas of Japan and Okhotsk. Mar Biol 1978, 47:243-250.

59. Rose M, Miller P, Baxter M, Appleton G, Crews H, Croasdale M: Bromine and iodine in 1997 UK total diet study samples. J Environ Monit 2001, 3:361-5.

60. Pavelka S, Vobecky M, Babicky A: Halogen speciation in the rat thyroid Simultaneous determination of bromine and iodine by short-term INAA. J Radioanal Nucl Chem 2008, 278:575-579.

61. Shiraishi K, Muramatsu Y, Los IP, Korzun VN, Tsigankov NY, Zamostyan PV: Estimation of dietary iodine and bromine intakes of Ukrainians. $J$ Radioanal Nucl Chem 1999, 242:199-202.

62. Kunachowicz H, Stibilj V, Stos K, Gosciniarek R: Studies on iodine content in daily diets and selected dairy products. Eur Food Res Technol 2000, 211:229-233.

63. Kucera J, lyengar GV, Randa Z, Parr RM: Determination of iodine in Asian diets by epithermal and radiochemical neutron activation analysis. $J$ Radioanal Nucl Chem 2004, 259:505-509.

64. Suzuki M, Tamura T: lodine intake of Japanese male university students: urinary iodine excretion of sedentary and physically active students and sweat iodine excretion during exercise. J Nutr Sci Vitaminol 1985, 31:409-415.

65. Yabu Y, Miyai K, Hayashizaki S, Endo Y, Hata N, lijima Y, Fushimi R: Measurement of iodide in urine using the iodide-selective electrode. Endocrinol Jpn 1986, 33:905-911.

66. Yabu Y, Miyai K, Endo Y, Hata N, lijima Y, Hayashizaki S, Fushimi R, Harada T, Nose O, Kobayashi A, Matsuzuka F, Kuma K: Urinary iodide excretion measured with an iodide-selective ion electrode: studies on normal subjects of varying ages and patients with thyroid diseases. Endocrinol Jpn 1988, 35:391-398.

67. Nagataki S: Status of iodine nutrition in Japan. Nagasaki, Japan: Nagasaki University School of Medicine. IDD Newsltr; 1993:9:11.

68. Tsuda K, Namba H, Nomura T, Yokoyama N, Yamashita S, Izumi M, Nagataki S: Automated measurement of urinary iodine with use of ultraviolet irradiation. Clin Chem 1995, 41:581-585

69. Ishigaki K, Namba H, Takamura N, Saiwai H, Parshin V, Ohashi T, Kanematsu T, Yamashita S: Urinary iodine levels and thyroid diseases in children; comparison between Nagasaki and Chernobyl. Endocr J 2001, 48:591-595.

70. Takamura N, Hamada A, Yamaguchi N, Matsushita N, Tarasiuk I, Ohashi T, Aoyagi K, Mine M, Yamashita S: Urinary iodine kinetics after oral loading of potassium iodine. Endocr J 2003, 50:589-593.

71. Zimmermann MB, Ito Y, Hess SY, Fujieda K, Molinari L: High thyroid volume in children with excess dietary iodine intakes. Am J Clin Nutr 2005, 81:840-844.

72. Tomoda C, Kitano H, Uruno T, Takamura Y, Ito Y, Miya A, Kobayashi K, Matsuzuka F, Amino N, Kuma K, Miyauchi A: Transcutaneous iodine absorption in adult patients with thyroid cancer disinfected with povidone-iodine at operation. Thyroid 2005, 15:600-603

73. Fuse $Y$, Saito $N$, Tsuchiya T, Shishiba Y, Irie M: Smaller thyroid gland volume with high urinary iodine excretion in Japanese schoolchildren: normative reference values in an iodine-sufficient area and comparison with the WHO/ICCIDD reference. Thyroid 2007, 17:145-155.

74. Miyai K, Tokushige T, Kondo M, lodine Research Group: Suppression of thyroid function during ingestion of seaweed "Kombu" (Laminaria japonoca) in normal Japanese adults. Endocr J 2008, 55:1103-1108.

75. Orito Y, Oku H, Kubota S, Amino N, Shimogaki K, Hata M, Manki K, Tanaka Y, Sugino S, Ueta M, Kawakita K, Nunotani T, Tatsumi N, Ichihara K,
Miyauchi A, Miyake M: Thyroid function in early pregnancy in Japanese healthy women: relation to urinary iodine excretion, emesis, and fetal and child development. J Clin Endocrinol Metab 2009, 94:1683-1688.

doi:10.1186/1756-6614-4-14

Cite this article as: Zava and Zava: Assessment of Japanese iodine intake based on seaweed consumption in Japan: A literature-based analysis. Thyroid Research 2011 4:14.

\section{Submit your next manuscript to BioMed Central and take full advantage of:}

- Convenient online submission

- Thorough peer review

- No space constraints or color figure charges

- Immediate publication on acceptance

- Inclusion in PubMed, CAS, Scopus and Google Scholar

- Research which is freely available for redistribution

Submit your manuscript at www.biomedcentral.com/submit
Ciomed Central 